have not heard from him since, and theretore conclude that he has continued well. Since then I have treated many cases, so that I have ceased to take note of them, and I have been invariably suecessful.

I can confidently recommend this treatment; the cure is well worth all the suffering consequent upon the inflammation of the bladder. The only difference I have sines made in the treatment is that $I$ inject two drachms of the solution at a time; the patient sometimes complains of feeling drunk, the alcohol affeeting the brain.

The points to be careful about are (1) the bladder must be empty of urine ; (2) the solution must be injected into the bladder ; it sometimes escapes unless care is taken to make the joining of the syringe and catheter secure; (3) the patient must retain it as long as he possibly can. I have never treated a woman or girl in this way, but $I$ have no doubt it would be as successfal as in men and boys. As yet this is but a crude statement. I would like to be able to tell more about the parasite after it is ejected from the bladder in the urine. I have as yet failed in making any satisfactory investigations in this direction; in the future I may be able to finish my inquiry. I have never found anything more serious than the inflammation resulting from this treatment; it is painful and requires great resolution on the part, of the patient. I adopt it always without fear, and as yet have had the best results.

Pieterkaritzburg.

\section{ACUTE STRANGULATION OF THE SMALL AND LARGE INTESTINES.}

BY M. C. SYKES, L.R.C.P. LOND., M.R.C.S., HOUSE-SURGEON, BECKETT HOSPITAL, BARNSLEY.

A. $\mathrm{N}-$, aged ten years, was admitted into this hospital on February 6 th, suffering from a compound fracture of his right forearm, a wound over his left eye, and a slight contusion helow the left Poupart's ligament. On admission he complained of pain in the hypegastric region, which was relieved at once by drawing off his urine. The wound of forearm and eyelid healed in six days. He had no pain after the first night. His bowels were regular, he passed his urine, and appeared ready for sending home. He was sent out on Feb. 18:h. On arriving home he had some cakes and tea given him ; this would be about six in the evening, and at one o'clock the following morning he was seized with pain, followed by sickness and diarrbcea. I saw him the next morning. He had been sick all night; no diarrhoea or motion then complained of. He had pain in the right iliac fossa; the pain was not very intense. Nothing could be felt, I saw him again on the following morning. The symptoms had incleased : hiccough; abdomen tense; vomited food and medicines; no pain. I saw him again the next morning, being the fourth of the disease. He romited a great deal; hiccoughed; abdomen tense; no pain. He had not had a passage since the first attack of diarrhoa. He died during this visit. His temperature was never more than $994^{\circ} \mathrm{F}$.

I made a post-mortem examination, and found the following morbid changes:-A piece of the small intestine, ileum, was perforated (no escape of freces), and had formed adhesions to the ascending colon. It was also strangulated here by recent inflammatory bands, and also slightly twisted. The bowel here was empty. The commencement of the large gut was constricted by bands of fibrous tissue crossing it, and convected to the iliac fossa, and thickersed by inflammatory products. It was completely strangulated by one of the bands of fibrons tissue, and closed off from the general peritoneal cavity by local peritonitis. A collection of pus was also encloied by the peritoneum around the upper portion of the cecum. There was not general peritunitis ; it was localised entir ly to the right iliac fossa. There was no other visceral misch!ef or disease of the bones or a previous history of strumous disease.

Remarles. - This was a very obscure case from the beginning of the sickness and diarthoe. It could not possibly be connected with the arcident. He had only a slight pain below the left Poupart's ligament during the first nisht after injury. His bswels were quite regnlar, no sickness, and could pass his urine during the twelve days he was in the hospital. One is bound to believe that his intestinal trouble was due to some irritant, possibly the cakes, as he had only taken them six hours when sickness and diarrincea set in. It is remarkable in this that severe diarnhoea should precede the strangulation.

\section{de}

\section{HOSPITAL PRACTICE, BRITISH AND FOREIGN.}

Nulla autem est alia pro certo noscendi via, nisi quamplorimas et morboram et dissectionum historias, tum aliorum tum proprins collectas habere, et inter se comparare.-Mosgagr De Sed. et Caus. Alorb, lib. iv. Procmiom.

\section{ST. THOMAS'S HOSPITAL.}

SOME CASES IN WHICH OYARIOTOMY WAS PERFORMED.

\section{(Under the care of Mr. SYDNEY JONES.)}

CAse 1. Unilocular Cyst of Left Ovary; Recovery.$\mathrm{H} . \mathrm{M}^{\prime} \mathrm{C}-$, aged twenty-five, single. During the last twelve months has lost flesh; six months ago was told by her friends that she was getting stouter, but until two months since did not notice anything herself; she then noticed a swelling chiefly on the left side of abdomen, and a fortnight later had severe cramping pain, not accompanied by vomiting, which lasted three days. Catamenia regular; rather profuse. On admission a very large ovarian tumour completely filled up abdominal cavity, apparently unilocular. Eleven days after admission ovariotomy was performed under antiseptic precautions. One adhesion of recent origin was found, and the cyst, which proved to be unilocular and connected with left ovary, was removed, the pedicle having beeo secured with silk ligature. A suppository containing half a grain of morphia was given immediately after the operation, and the patient had a good night, being only disturbed by occasional vomiting consequent on the ether. Next day still some vomiting and much flatulence, also pain in region of left clavicle. Pulse 124. Third day: Vomited greenish fluid at intervals. Pulse 120. Allowed iced milk and soda water. Temperature at 4 P.M., $101 \cdot 6^{\circ}$. Hypodermic injection of a quarter of a grain of morphia given six times during the day, also a dose of medicine containing seven minims of sedative solution of opium, Fifth day: The opium, which had been given on the fourth day, was discontinued. Still suffers from flatulence. Pulse 85 ; temperature last night $102^{\circ}$, this morning $98^{\circ} 8^{\circ}$. Sixtla day : Allowed four ounces of wine, extract of meat, chicken jelly, and barley water. Wound dressed, and deep stitches removed, the parts being supported and approximated by broad strips of strapping. No discharge. Seventh day: Simple enema given. Ninth day : Urine contained albumen and a few blood corpuscles. After the fifth day the temperature did not rise above $99 \cdot 6^{\circ}$, and the patient rapidly recovered, was allowed to get up on the sixteenth day, and left cured on the twenty-sixth day afrer operation.

CASE 2. Tumour of Right Broad Ligament; Recovery.E. E- aged thirty, married ; one child, ased eleven. Catamenia regular; noticed a swelling on right side of abdomen about ten months sgo, this gradually enlarged without pain ; large ovarian tumour projecting more to right side of abdomeu. Four days after admission antiseptic ovariotomy was performed, adhesions extensive and numereas, the tumour first emptied of its fluid contents (twelve pints, claret colour), and then gradually separated from the abdominal wall in front and intestines behind, most of the arkesions, which were firm, being divided between a double livature ; the sac appeared to be euclcsed in a fibrous capsule, and was found to have been developed in the right broad ligament, the left ovary was free. A morphia suppository was administered after the operation, but she became very restless later in the day, and had a subcutaneous injection of a quarter of a grain of morphia. Vomited tbree times during the day, and twice during the following night; urine drawn off by means of catheter. Next day unine diawn off every eight hours; puise 142; two irijections of morphia given. Catamenia came on; no vomiting. For some days she was troubled by a cough, which was reliered by ipecacuanha wine and bromide of potassium. The wound was dressed on the eighth, eleventh, 